\title{
Influência da idade e do tamanho do rebanho na soroprevalência da Leucose Enzoótica Bovina em rebanhos produtores de leite tipo B, na região norte do estado do Paraná*
}

\section{Herd size and age influences at Enzootic Bovine Leukosis serum prevalence in dairy herds (type B milk) in north of Paraná state*}

\author{
Luis Álvaro Leuzzi Júnior, ${ }^{\star *}$ José da Silva Guimarães Junior, ${ }^{\star \star \star}$ Roberta Lemos Freire, ${ }^{\star \star \star}$ Alice Fernandes Alfieri, ${ }^{\star \star \star}$ \\ Amauri Alcindo Alfieri ${ }^{\star \star \star}$
}

\begin{abstract}
Resumo
A soroprevalência da Leucose Enzoótica Bovina (LEB), em fêmeas com idade superior a 15 meses provenientes de rebanhos produtores de leite do tipo $\mathrm{B}$, na região norte do estado do Paraná foi determinada pela técnica de imunodifusão em ágar-gel. Foram avaliados 624 soros sangüíneos de animais pertencentes a 23 rebanhos de oito municípios. Identificaram-se 254 $(40,7 \%)$ animais soropositivos, distribuídos em todos os $23(100 \%)$ rebanhos avaliados. Animais com idade superior a dois anos tiveram risco de infecção 2,7 vezes maior $(1,6<O R<4,5)$ quando comparados aos animais com idade inferior. $A$ prevalência da infecção foi estatisticamente superior $(p=0,043)$ em rebanhos com menos de 100 animais. Estes resultados demonstram que a LEB está disseminada nos rebanhos produtores de leite tipo B, incluídos neste estudo.
\end{abstract}

Palavras-chave: bovinos, leucose enzoótica bovina, vírus da leucemia bovina, sorologia, imunodifusão em ágar gel.

\begin{abstract}
The serum prevalence of Enzootic Bovine Leukosis (EBL) in females older than 15 months of type $B$ milk producing herds in the northern region of Paraná state was determined by agar gel immunodiffusion (AGID) technique. Serum samples from 624 cows from 23 herds of 8 districts were evaluated. All $23(100 \%)$ herds and $254(40,7 \%)$ serum samples were positives for bovine leukemia virus antibodies. Cows over 2 years age had an infection's risk of 2,7 times more $(1,6<$ OR $<4,5)$ than the others age groups studied. The infection's prevalence was statistically higher $(p=0,043)$ in those herds with less than 100 animals. The results showed that EBL is disseminated in type B milk producing dairy herds included in this study.
\end{abstract}

Keywords: cattle, Enzootic Bovine Leukosis, bovine leukemia virus, serology, agar gel immunodiffusion.

\section{Introdução}

A Leucose Enzoótica Bovina (LEB) é uma infecção de evolução crônica em bovinos ocasionada por um retrovírus, o vírus da leucemia bovina (BLV), classificado no gênero Deltaretrovírus. O BLV infecta linfócitos $B$ e pode induzir transformação neoplásica. Clinicamente, a LEB pode apresentar-se nas formas de linfossarcoma ou de linfocitose persistente que comprometem 2 a $5 \%$ e 20 a $30 \%$ dos animais soropositivos, respectivamente. Apesar da maioria das infecções pelo BLV ser subclínica, os animais infectados tornam-se portadores do vírus e potenciais transmissores para os animais susceptiveis (Johnson e Kaneene, 1992, Murphy et al., 1999).

Tanto na forma clínica quanto, particularmente, na subclínica a sorologia é o método mais rápido e eficaz para a realização do diagnóstico da infecção pelo BLV. Para o diagnóstico indi- vidual ou de rebanho são, mais freqüentemente, utilizadas as técnicas de imunodifusão em ágar-gel (IDAG), que identifica anticorpos contra as glicoproteínas gp51 e gp30 do envelope viral, e de ELISA, que detecta anticorpos contra a proteína p24 presente no capsídeo do BLV (Evermann, 1992).

A LEB encontra-se amplamente disseminada nos rebanhos bovinos de todo o mundo (Miller e Van Der Maaten, 1982; Johnson e Kaneene, 1992). As taxas de animais e/ou rebanhos infectados variam consideravelmente na dependência da faixa etária, da aptidão do rebanho (corte/leite), do grau de tecnificação da pecuária e do tipo de manejo zootécnico-sanitário (Johnson e Kaneene, 1991b; Sargeant et al., 1997). Na maioria dos inquéritos sorológicos são encontradas taxas de soropositividade entre 40 a $70 \%$ e 60 a $90 \%$ para animais e rebanhos, respectivamente (Johnson e Kaneene, 1991a; Digiacomo, 1992; Shirley et al., 1997).

* Apoio financeiro: CNPq, CAPES e CPG/UEL.

** Médico-veterinário, aluno do Programa de Pós-Graduação em Sanidade Animal (nível: Mestrado), Universidade Estadual de Londrina.

*** Laboratório de Virologia Animal, Departamento de Medicina Veterinária Preventiva, Centro de Ciências Agrárias, Universidade Estadual de Londrina, Londrina/PR. e-mail: alfieri@uel.br 
No Brasil, a freqüência de ocorrência de animais soropositivos foi avaliada em vários estudos realizados em regiões geograficamente distintas. Os resultados demonstraram a presença do vírus em rebanhos de todas as regiões estudadas, com prevalência variando de $9,1 \%$ no estado do Ceará a $54,3 \%$ no estado do Rio de Janeiro (Romero e Rowe, 1981; Santos et al., 1985; Flores et al., 1990; Abreu, 1993; Birgel JR. et al., 1995; Moraes, 1996). No estado do Paraná há apenas dois relatos sobre a freqüência de ocorrência da LEB em rebanhos com aptidão leiteira, nos quais foram encontradas taxas de 20,7\% (Kantek et al., 1983) e de 27,4\% (Carvalho et al., 1996) de animais soropositivos. Entretanto, a grande maioria dos inquéritos soroepidemiológicos da infecção pelo BLV no Brasil têm determinado a prevalência sem associar o resultado encontrado às características do rebanho e/ou manejo.

$O$ presente trabalho teve como objetivo determinar a prevalência da infecção pelo BLV em rebanhos bovinos com manejo tecnificado, produtores de leite do tipo $B$ na bacia leiteira da região norte do estado do Paraná, bem como associar a taxa de animais sororreagentes à faixa etária e ao tamanho do rebanho.

\section{Material e métodos}

\section{Tamanho da amostra e amostragem}

Inicialmente foram mapeados todos os rebanhos bovinos com aptidão leiteira, produtores de leite classificado como tipo B, segundo as normas sanitárias de produção e criação regulamentadas pelo Ministério da Agricultura, Pecuária e Abastecimento, pertencentes à bacia leiteira da região norte do estado do Paraná. Em oito municípios (Apucarana, Arapongas, Cambé, Cambira, Londrina, Mandaguari, Rolândia e Tamarana) foram identificados 24 rebanhos. Destes, 23 concordaram em participar do estudo, totalizando uma população-alvo de 4.064 animais.

Para cada propriedade foi determinado o tamanho de amostra necessário para detectar pelo menos um animal positivo, considerando-se uma prevalência estimada de $10 \%$ e nível de significância de 5\% (Cannon e Roe, 1982). Utilizaram-se 624 animais, resultantes da soma das amostras calculadas para cada propriedade (Tabela 1). A amostragem foi feita de forma sistemática, utilizando-se para sorteio as fichas de registro dos animais das propriedades. Obtiveram-se também informações referentes ao tamanho do rebanho, à idade dos animais e às medidas de controle e profilaxia da infecção pelo BLV adotadas nos rebanhos.

A localização geográfica dos municípios que participaram deste estudo está entre as latitudes $50^{\circ} 30^{\prime} \mathrm{w}$ e $51^{\circ} 45^{\prime} \mathrm{w}$ e os paralelos $23^{\circ} 05^{\prime}$ s e $23^{\circ} 50^{\prime}$ s. Na Figura 1 encontra-se o mapa da região norte do estado do Paraná, onde foram colhidas amostras de sangue dos bovinos para o diagnóstico da LEB.

\section{Coleta de material}

No período de janeiro a março de 2000 foram coletadas 624 amostras de sangue provenientes de fêmeas bovinas, em idade de reprodução ( $\geq$ de 15 meses). Os soros sangüíneos, obtidos após a formação do coágulo, foram centrifugados a $2000 \times \mathrm{g} / 5 \mathrm{~min}$ e estocados a $-20^{\circ} \mathrm{C}$.
Tabela 1: Amostras de soro sangüíneo de bovinos analisadas por imunodifusão em ágar-gel para o diagnóstico da infecção pelo vírus da leucemia bovina em rebanhos produtores de leite tipo B na região norte do estado do Paraná, Brasil, 2001.

\begin{tabular}{|c|c|c|c|}
\hline \multicolumn{3}{|c|}{ REBANHO } & \multirow{2}{*}{$\begin{array}{c}N^{\circ} \text { de } \\
\text { Soros } \\
\text { Avaliados } \\
\end{array}$} \\
\hline Categoria & $\begin{array}{c}\mathrm{N}^{0} \text { de } \\
\text { Identificação }\end{array}$ & $\begin{array}{c}\mathrm{N}^{\circ} \text { Total de } \\
\text { Animais }\end{array}$ & \\
\hline \multirow[t]{7}{*}{ Pequeno' } & 5 & 80 & 25 \\
\hline & 6 & 82 & 25 \\
\hline & 7 & 51 & 24 \\
\hline & 10 & 37 & 27 \\
\hline & 15 & 96 & 25 \\
\hline & 19 & 57 & 22 \\
\hline & 21 & 51 & 25 \\
\hline \multirow[t]{16}{*}{ Grande $^{2}$} & 1 & 335 & 28 \\
\hline & 2 & 345 & 35 \\
\hline & 3 & 334 & 30 \\
\hline & 4 & 194 & 26 \\
\hline & 8 & 132 & 26 \\
\hline & 9 & 109 & 26 \\
\hline & 11 & 110 & 25 \\
\hline & 12 & 345 & 34 \\
\hline & 13 & 118 & 26 \\
\hline & 14 & 126 & 26 \\
\hline & 16 & 610 & 34 \\
\hline & 17 & 278 & 28 \\
\hline & 18 & 208 & 27 \\
\hline & 20 & 172 & 27 \\
\hline & 22 & 127 & 28 \\
\hline & 23 & 107 & 25 \\
\hline TOTAL & & 4.064 & 624 \\
\hline
\end{tabular}

Para a avaliação da taxa de positividade por tamanho do rebanho, fez-se a distribuição em duas categorias: i) Rebanhos pequenos (até 100 animais) com sete observações; ii) Rebanhos grandes ( $>100$ animais) com 16 observações. A taxa de positividade em diferentes faixas etárias também foi avaliada pela distribuição dos animais em três categorias: i) até dois anos de idade $(n=105)$; ii) entre dois e quatro anos $(n=237)$; iii) acima de quatro anos de idade $(n=282)$.

\section{Imunodifusão em ágar-gel}

Para a detecção de anticorpos contra o BLV foi empregado o método de imunodifusão em ágar-gel segundo Miller e Van Der Maaten (1976 e 1977). A técnica foi realizada com ágar (Nobre, Difco) na concentração final de 0,8\% em PBS/EDTA $\mathrm{pH} 7,2\left(1,45 \mathrm{M} \mathrm{NaCl} ; 3 \mathrm{mM} \mathrm{KCl} ; 8 \mathrm{mM} \mathrm{Na}_{2} \mathrm{HPO}_{4} ; 1,5 \mathrm{mM} \mathrm{KH}_{2} \mathrm{PO}_{4}\right.$; $1 \mathrm{mM}$ EDTA dissódico). $\mathrm{O}$ ágar foi distribuído em placas de $50 \mathrm{~mm}$ de diâmetro e, após a solidificação, foram perfuradas sete cavidades (uma central e seis periféricas) de $6 \mathrm{~mm}$ de diâmetro cada. Na cavidade central foram depositados $50 \mathrm{~mL}$ de antígeno do BLV constituído por sobrenadante de células de linhagem contínua cronicamente infectadas com o BLV (Empresa Brasileira de Pesquisa Agropecuária / EMBRAPA, Centro Nacional de Pesquisas em Suínos e Aves, Concórdia, SC). Cada cavidade periférica foi preenchida com $50 \mathrm{~mL}$ do soro não diluído, previamente inativado a $56^{\circ} \mathrm{C} / 30 \mathrm{~min}$. $\mathrm{Em}$ 
todas a placas, como controles positivo e negativo, foram dispensados soros de bovinos comprovadamente infectado com o BLV e livre da infecção, respectivamente. As placas foram incubadas à temperatura ambiente por 72 horas e a avaliação final dos resultados foi realizada pela ausência ou presença de linhas de precipitação.

\section{Análise estatística}

Para avaliar as diferenças entre as proporções de animais positivos nas três faixas etárias e nos dois tamanhos de rebanhos estudados, utilizou-se como medida de associação o odds ratio e o respectivo intervalo de confiança de $95 \%$, e o teste de Qui-quadrado $\left(\chi^{2}\right)$, com nível de significância de $5 \%$. Para a realização dos cálculos foi empregado o programa Epilnfo 6,04b (Dean et al., 1992).

\section{Resultados e discussão}

Das 624 amostras de soros avaliadas quanto à presença de anticorpos anti-BLV pela técnica de IDAG, $254(40,7 \%)$ formaram linhas de precipitação específicas para o antígeno sendo consideradas positivas. Em 100\% dos 23 rebanhos bovinos estudados foram encontrados animais soropositivos para o BLV. Estes resultados demonstram que a infecção por esse retrovírus está amplamente disseminada nos rebanhos bovinos, produtores de leite do tipo $B$, pertencentes à bacia leiteira da região norte do estado do Paraná.

Kantek et al. (1983) realizaram no estado do Paraná um levantamento sorológico para a identificação de animais soropositivos para o BLV. A amostragem, também estabelecida por métodos estatísticos, compreendeu 695 soros de bovinos de 184 rebanhos com aptidão leiteira, provenientes de 43 municípios, atendidos pelas maiores cooperativas e indústrias de laticínios das principais regiões produtoras do estado. Pela técnica de IDAG foram considerados positivos $144(20,7 \%)$ animais e $75(40,8 \%)$ rebanhos.

Também no Paraná, no pólo regional de Londrina, Carvalho et al. (1996) investigaram pela técnica de IDAG a presença de anticorpos específicos para a gp51 do BLV em 985 soros provenientes de 14 rebanhos. Neste levantamento foram avaliados tanto animais com aptidão para carne (raça nelore) quanto para leite (raça holandesa). Nenhum animal da raça nelore apresentou anticorpos específicos para o BLV. No entanto, $18,4 \%$ dos animais da raça holandesa foram considerados soropositivos com $83,3 \%$ dos rebanhos leiteiros infectados. Em rebanhos produtores de leite tipo B 27,4\% dos animais foram positivos.

Considerando que tanto no presente estudo quanto no de Kantek et al. (1983), somente foram avaliados rebanhos bovinos com aptidão leiteira, evidencia-se que a prevalência da

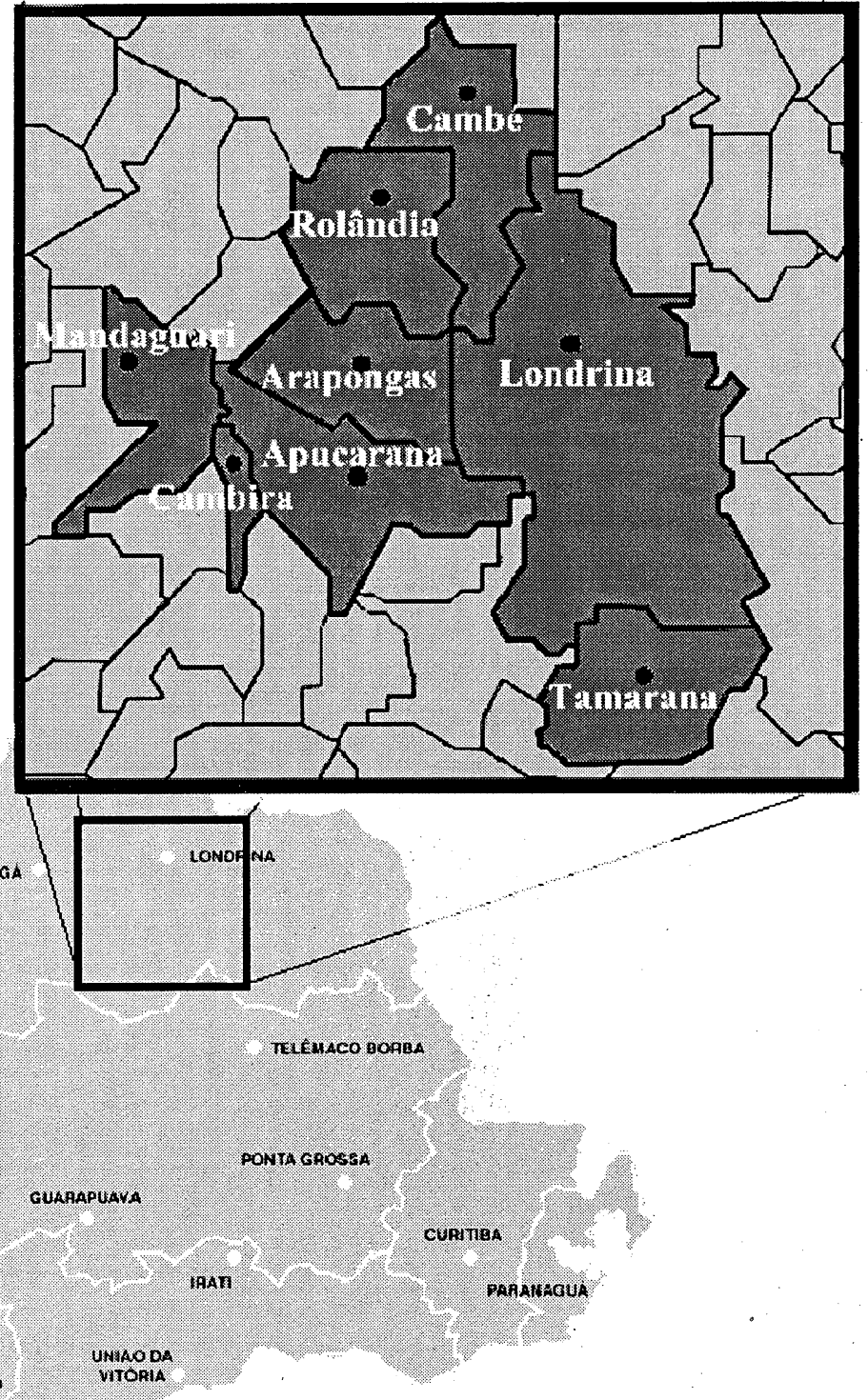

Figura 1: Localização geográfica, na região norte do estado do Paraná, dos municípios incluídos no estudo sorológico da prevalência da Leucose Enzoótica Bovina em rebanhos bovinos produtores de leite tipo $B$.

infecção aumentou consideravelmente em duas décadas. Apesar de que em nosso trabalho foram avaliados apenas rebanhos bovinos produtores de leite tipo $B$ da região norte do estado do Paraná e que Kantek et al. (1983) trabalharam com rebanhos provenientes das principais bacias leiteiras de todo o estado, a análise comparativa dos resultados demonstra que houve um incremento de $96,6 \%$ e de $145,1 \%$ nas taxas de infecção dos animais e dos rebanhos, respectivamente.

Embora Carvalho et al. (1996) não tenham trabalhado com um número de rebanhos representativo de uma região geográfica, podemos observar que, em um período de apenas cinco anos, houve um incremento de $48 \%$ na taxa de infecção para $\circ \mathrm{BLV}$ em animais produtores de leite do tipo B. Este dado revela uma situação epidemiológica preocupante com relação à infecção da LEB nos rebanhos leiteiros da região norte do estado do Paraná. 
Inúmeras situações podem ter contribuído para estes aumentos significativos nas taxas de infecção observadas no presente trabalho, entre elas: i) a inexistência de uma ação oficial de controle da LEB em todo o Brasil; ii) a livre comercialização de animais soropositivos; iii) a não-realização rotineira de diagnóstico; iv) a não-implementação, em nível de propriedade, de medidas de controle e profilaxia da infecção; v) o desconhecimento dos criadores, e de parte da classe médico-veterinária, sobre os reais prejuízos econômicos que podem ser determinados pela infecção; vi) o tipo de amostragem do presente trabalho, que foi realizado quase que exclusivamente em criações tecnificadas e com manejo intensivo.

Entretanto, deve-se ressaltar que a amostragem do presente trabalho não foi realizada proporcionalmente ao tamanho dos rebanhos avaliados, mas sim, de forma a encontrar pelo menos um animal soropositivo por rebanho. Dessa forma, pode haver um desvio em relação ao real valor da prevalência encontrada.

Johnson e Kaneene (1991b) encontraram uma associação da LEB com a faixa etária dos animais. A prevalência e a incidência da infeç̧ão foram menores em animais jovens, sendo que estes, quando positivos, provavelmente contaminaram-se no período prénatal. A incidência e a prevalência da LEB aumentaram significativamente a partir de 16 a 24 meses de idade.

Nos 23 rebanhos estudados também foi avaliada a taxa de infecção pelo BLV em animais de diferentes faixas etárias. Nos três grupos etários estudados foi constatada a presença de animais soropositivos, com taxas crescentes em relação ao aumento da idade dos animais. A diferença encontrada nas taxas de infecção entre as faixas etárias $\leq 2$ anos, $>2$ e $\leq 4$ anos $e>4$ anos foi estatisticamente significativa $(p=0,000016)$ (Tabela 2). Os aumentos significativos nas taxas de infecção em relação aos diferentes grupos etários e ao tamanho dos rebanhos provavelmente são devidos à intensificação das práticas de manejo a que são submetidas as fêmeas após o primeiro parto. Estes animais são ordenhados no mínimo duas vezes ao dia e estão em fase ativa de reprodução, sendo submetidos a fatores de risco que predispõem à infecção como: i) palpação retal para a inseminação artificial e para o diagnóstico de gestação; ii) coleta de sangue para o monitoramento semestral de brucelose ou mes-

Tabela 2: Distribuição, por faixa etária, dos percentuais de bovinos soropositivos para a Leucose Enzoótica Bovina provenientes de rebanhos produtores de leite tipo $B$, na região norte do Estado do Paraná, Brasil, 2001

\begin{tabular}{lcccc}
\hline Faixa & Média da & \multicolumn{3}{c}{ No de Amostras } \\
\cline { 3 - 5 } Etária/Anos & Idade/Anos & Total & Negativas & Positivas $(\% ;$ IC 95\%) \\
\hline I. $\leq 2$ & 1,56 & 105 & 81 & $24(22,8 ; 15,2-32,0)$ \\
II. $>2$ e $\leq 4$ & 3,05 & 237 & 145 & $92(38,8 ; 32,5-54,9)$ \\
III. $>4$ & 6,0 & 282 & 144 & $138(48,9 ; 42,9-54,9)$ \\
\hline TOTAL & 4,13 & 624 & 370 & $254(40,7 ; 36,8-44,7)$ \\
\hline
\end{tabular}

$\chi^{2}(22,12) ; P(0,000016)$ mo diagnóstico sorológico de outras doenças infecciosas iii) injeções intramusculares para a vacinação contra doenças infecciosas da reprodução, controle de endo e ecto-parasitas, suplementação de vitaminas e minerais com produtos injetáveis, tratamentos de infecções do casco, tristeza parasitária bovina e infecções da glândula mamária, entre outras (Johnson e Kaneene, 1991b).

A Tabela 3 apresenta a percentagem de infecção e a média de idade por rebanho, bem como o número de animais positivos e negativos, distribuídos por rebanho avaliado. $A$ análise destes dados revelou que a faixa etária também influenciou a prevalência da LEB. Rebanhos com média de idade acima de quatro anos apresentaram diferença altamente significativa $(p=0,0007)$ quanto à prevalência da LEB.

Tabela 3: Distribuição da média da idade e da percentagem de bovinos soropositivos para a Leucose Enzoótica Bovina em rebanhos produtores de leite tipo B da região norte do Estado do Paraná, Brasil, 2001

\begin{tabular}{ccrccc}
\hline REBANHO/ & MÉDIA DE & \multicolumn{2}{c}{ N $^{\circ}$ DE ANIMAIS } & TOTAL \\
IDENTIFICAÇÃO & IDADE/ANOS & POSTIVOS (\%) & NEGATIVOS & \\
\hline P1 & 4,1 & $13(46,4 \%)$ & 15 & 28 \\
P2 & 3,7 & $1(2,9 \%)$ & 34 & 35 \\
P3 & 4,4 & $19(63,3 \%)$ & 11 & 30 \\
P4 & 5,4 & $13(50,0 \%)$ & 13 & 26 \\
P5 & 3,2 & $6(24,0 \%)$ & 19 & 25 \\
P6 & 5,0 & $11(44,0 \%)$ & 14 & 25 \\
P7 & 4,4 & $20(83,3 \%)$ & 4 & 24 \\
P8 & 3,8 & $6(23,1 \%)$ & 20 & 26 \\
P9 & 3,6 & $10(38,5 \%)$ & 16 & 26 \\
P10 & 5,1 & $15(55,5 \%)$ & 12 & 27 \\
P11 & 3,4 & $17(68,0 \%)$ & 8 & 25 \\
P12 & 3,8 & $18(52,9 \%)$ & 16 & 34 \\
P13 & 4,3 & $8(30,8 \%)$ & 18 & 26 \\
P14 & 3,1 & $8(30,8 \%)$ & 18 & 26 \\
P15 & 6,9 & $16(64,0 \%)$ & 9 & 25 \\
P16 & 3,8 & $8(23,5 \%)$ & 26 & 34 \\
P17 & 4,2 & $11(39,3 \%)$ & 17 & 28 \\
P18 & 4,1 & $7(25,9 \%)$ & 20 & 27 \\
P19 & 3,7 & $6(27,3 \%)$ & 16 & 22 \\
P20 & 3,8 & $11(40,7 \%)$ & 16 & 27 \\
P21 & 4,8 & $8(32,0 \%)$ & 17 & 25 \\
P22 & 4,9 & $10(35,7 \%)$ & 18 & 28 \\
P23 & 3,6 & $12(48,0 \%)$ & 13 & 25 \\
\hline TOTAL & & $254(40,7 \%)$ & 370 & 624 \\
\hline & & & &
\end{tabular}

Em nenhum dos rebanhos estudados são adotadas medidas de controle e profilaxia para a LEB, como o diagnóstico para a identificação de animais portadores bem como o uso de agulhas e luvas de palpação descartáveis para cada animal. Com isto, a tendência natural é que à medida que os animais permanecem por mais tempo nos rebanhos, a probabilidade de novas infecções aumenta como observado neste trabalho.

A Tabela 4 apresenta os percentuais de animais sororreagentes ao BLV distribuídos de acordo com o tamanho do rebanho. As diferenças nas taxas de infecção para rebanhos considerados pequenos e grandes foram comparadas e mostraram que em rebanhos com menos de 100 animais a prevalência foi significativamente maior $(p=0,043)$. 
Tabela 4: Distribuição, pelo tamanho du :ebanho, dos percentuais de vacas provenientes de rebanhos produtores de leite do tipo $B$, na região norte do estado do Paraná, soropositivas para a Leucose Enzoótica Bovina, Brasil, 2001.

\begin{tabular}{|c|c|c|c|c|}
\hline TAMANHO DO & № MÉDIO & MÉDIA DA & № TOTAL & № POSITIVOS \\
\hline REBANHO & DE ANIMAIS & IDADE (ANOS) & AMOSTRAS & $(\% ;$ IC 95\%) \\
\hline Pequeno & 64,8 & 4,7 & 173 & $82(47,4 ; 39,7-55,1)$ \\
\hline \multicolumn{5}{|l|}{$\leq 100$ animais } \\
\hline Grande & 228,1 & 4,0 & 451 & $172(38,1 ; 33,6-42,7)$ \\
\hline \multicolumn{5}{|l|}{$>100$ animais } \\
\hline TOTAL & & & 624 & $254(40,7 ; 36,8-44,6)$ \\
\hline
\end{tabular}

$\chi^{2}(4,07) ; P(0,043)$

Os rebanhos pequenos e grandes eram constituídos por uma média de 64,8 e 228,1 animais, respectivamente. Deve-se considerar que, à exceção de um rebanho incluído na categoria grande, em todos os outros 22 rebanhos os animais eram submetidos a um tipo de manejo muito semelhante, apenas com diferenças mínimas peculiares a cada propriedade. Os animais eram ordenhados duas vezes ao dia e suplementados com volumoso (feno/silagem de milho) e ração.

Outro fator a ser considerado é a média de idade dos animais das categorias de rebanhos avaliadas. Os rebanhos pequenos e grandes eram constituídos por animais com uma média de 4,7 e 4,0 anos, respectivamente. Observa-se que, independentemente do tamanho do rebanho, a média de idade foi muito semelhante, estando ainda incluídos na faixa etária $>4$ anos na qual, neste estudo, a prevalência da LEB foi maior. Estes resultados sugerem que em rebanhos infectados, submetidos às mesmas práticas de manejo, 0 número total de animais no rebanho, além da faixa etária, pode interferir nas taxas de prevalência da LEB.

A Tabela 5 apresenta a análise estatística das associações de diferentes categorias de animais/rebanho frente ao resultado do teste de IDAG para o BLV.

De todos os rebanhos estudados, somente a propriedade $\mathrm{P} 2$, constituída por 345 animais dos quais foram avaliados 35 , adotava o manejo extensivo de criação. Os animais não recebiam súplementação, sendo alimentados exclusivamente a pasto. Este rebanho apresentou a menor taxa de animais sororreagentes dentre os 23 avaliados, com apenas $1(2,8 \%)$ animal de 6,2 anos de idade soropositivo para a LEB. Mesmo não sendo significativo, pois somente o rebanho P2 utilizava o manejo extensivo, este resultado abre a perspectiva para o desenvolvimento de novos trabalhos com ênfase na associação da prevalência da infecção pelo BLV em rebanhos com diferentes tipos de manejo nutricional (intensivo/extensivo).

Os resultados do presente trabalho demonstraram que a infecção pelo BLV alcança taxas preocupantes nos rebanhos bovinos produtores de leite do tipo $\mathrm{B}$, da região norte do estado do Paraná, e ocorre particularmente em animais com idade superior a quatro anos.

Tabela 5 - Análise estatística das variáveis de faixa etária e tamanho do rebanho frente aos resultados do teste de imunodifusão em ágar-gel para o diagnóstico sorológico da Leucose Enzoótica Bovina em rebanhos bovinos produtores de leite do tipo B, na região norte do estado do Paraná, Brasil, 2001.

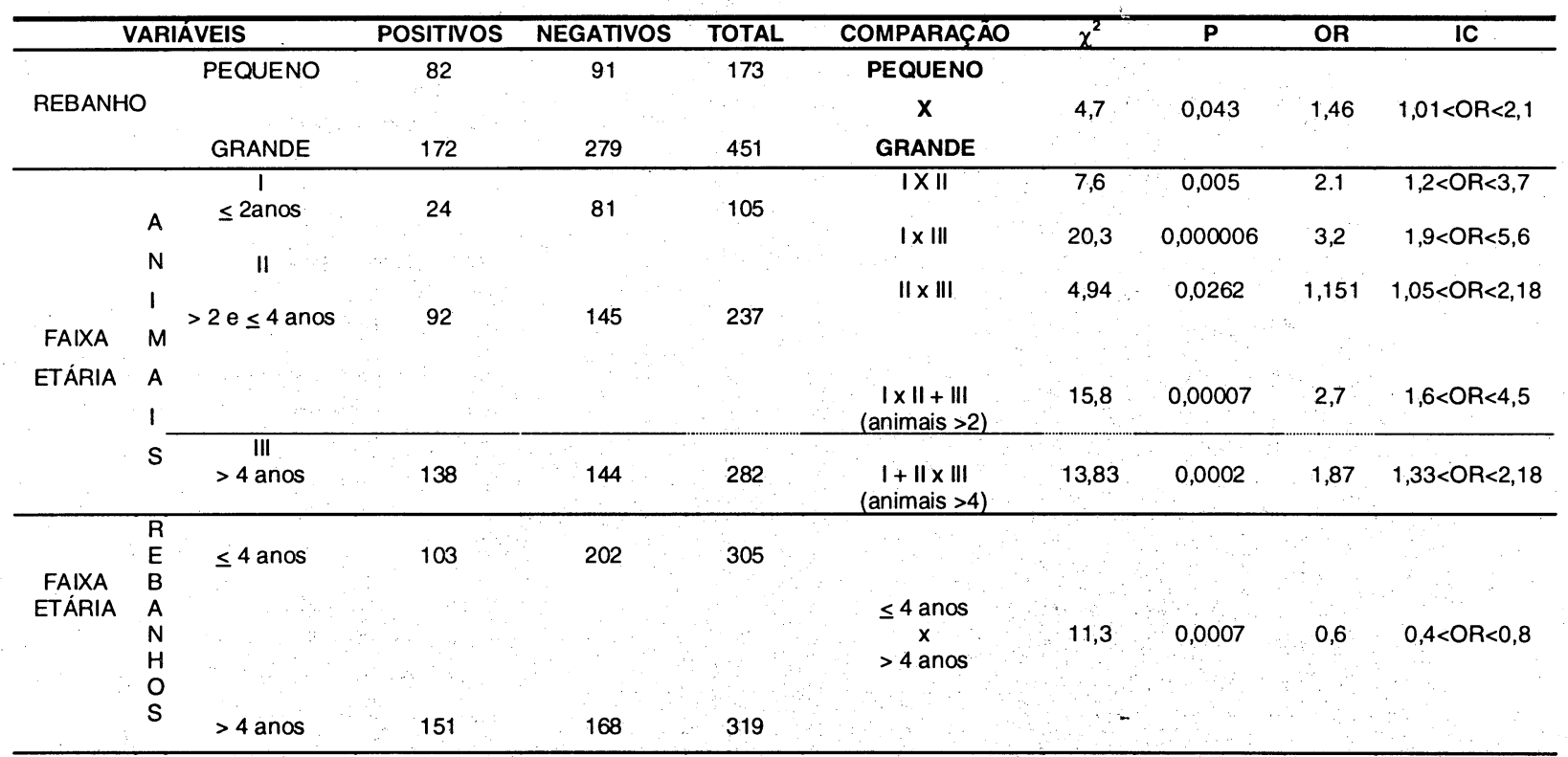

$\chi^{2}=$ Qui-Quadrado; $\mathrm{P}=$ Probabilidade; $\mathrm{OR}=$ Odds Ratio; $\mathrm{IC}=$ Intervalo de Confiança 
Considerando que em média de 2 a $5 \%$ dos animais infectados com o BLV desenvolvem o linfossarcoma e que este estudo abrangeu uma população de 4.064 animais com uma prevalência média de $40,7 \%$ podemos esperar um descarte prematuro de 50 a 83 animais, decorrente da forma maligna da infecção. Ainda como custos diretos e/ou indiretos da infecção devem ser consideradas as despesas com o tratamento de animais expressando os mais diversos sinais clínicos da infecção; a maior susceptibilidade a infecções intercorrentes; e a menor produção de leite dos animais soropositivos, particularmente aqueles com linfocitose persistente ou linfossarcoma (Digiacomo, 1992).

\section{Referências}

ABREU, J.M.G. Leucose enzoótica dos bovinos: prevalência de anticorpos séricos anti-vírus da leucose bovina em animais criados na bacia leiteira de Fortaleza, Estado do Ceará. 1993, 75p. Dissertação (Mestrado)-Faculdade de Medicina Veterinária e Zootecnia, Universidade de São Paulo, 1993.

BIRGEL JR., E.H., D'ANGELINO, J., BENESI, F.J. Prevalência da infecção pelo vírus da leucose dos bovinos, em animais da raça Jersey, criados no Estado de São Paulo. Pesq. Vet. Bras., v. 15, n. 4, p. 93-99, 1995.

CANNON, R.M., ROE, R.T. Livestock Disease Surveys: a Field Manual for Veterinarians. Canberra: Australian Government Publishing Service, 1982, p. 35.

CARVALHO, L., BENESI, J.F., BIRGEL JR. E.H., BIRGEL, E.H. Prevalência de anticorpos séricos antivírus da leucose dos bovinos em animais da raça holandesa preta e branca e zebuínos da raça nelore, criados no pólo regional de Londrina, estado do Paraná. Semina: Ciências Agrárias, v. 17, n. 1, p. 53-57, 1996.

DEAN, A.G., DEAN, J.A., BURTON, A.H., Epi Info, version 6: a Word processing, database and statistic program for epidemiology on microcomputers. Atlanta, Geórgia, USA: Center for Disease Control and Prevention (CDC), 1992. 302 p.

DIGIACOMO, R. F. The epidemiology and control of bovine leukemia virus infection. Vet. Med., n. 3, p. 248-257, 1992.

EVERMANN, J.F. A look at how bovine leukemia virus infection is diagnosed. Symposium on bovine leukemia virus infection. Vet. Med., n. 3, p. 272-278, 1992.

FLORES, E.F., WEIBLEN, R., REBELATO, M.C. Aspectos epidemiológicos da infecção pelo vírus da leucose bovina (VLB) na região central do Rio Grande do Sul. Hora Veterinária, v. 10, n. 58, p. 35-29, 1990.

JOHNSON, R., KANEENE, J.B. Bovine leukemia virus. Part I. Descriptive epidemiology, clinical manifestations, and diagnostic tests. The Compendium Food Animal., v. 13, n. 2, p. 315-324, 1991 a.
A somatória de todos estes prejuízos econômicos é considerável em uma atividade onde as margens de lucro são reduzidas, como na pecuária leiteira. Para minimizar este problema, tanto os pecuaristas quanto os técnicos deveriam conscientizar-se quanto à importância da adoção de medidas de controle da LEB. Com o objetivo principal de reduzir a disseminação da infecção no rebanho, medidas de baixo custo, como a interferência nos fatores de risco de transmissão do BLV deveriam ser implementadas para que, pelo menos a médio prazo, a prevalência da infecção nos rebanhos e nos animais seja reduzida.

JOHNSON, R., KANEENE, J.B. Bovine leukemia virus. Part II. Risk factors of transmission. The Compendium Food Animal, v. 13, n. 4, p. 681 691, $1991 \mathrm{~b}$.

; Bovine Leukaemia Vírus and Enzootic Bovine Leukosis. Veterinary Bulletin, v. 62, n. 4, p. 287-312, 1992.

KANTEK, C.E., KRUGER, E.R., WELTE, V.R. Prevalência do vírus da leucose enzoótica bovina no rebanho leiteiro do Paraná. Pesq. Vet. Bras., v. 3, n. 4, p. 125-129, 1983.

MILLER, J.M., VANDER MAAT.EN, M.J. Serological detection of bovine leukemia virus infection. Vet. Microbiol., v. 1, p. 195, 1976.

MILLER, J.M., VAN DER MAATEN, M.J. Use of glycoprotein antigen in the immunodiffusion test for bovine leukemia virus antibodies. Eur. J. Cancer, v. 13, p. 1.369, 1977.

; Bovine Leukosis - Its importance to the dairy industry in the United States. J. Dairy Sci., v. 65, p. 2.194-2.203, 1982.

MORAES. M.P. Levantamento sorológico da infecção pelo vírus da leucose bovina nos rebantios leiteiros do estado do Rio Grande do Sul, Brasil. Ciência Rural, v. 26, n. 2, p. 257-262, 1996.

MURPHY, F.A., GIBBS, E.P.J., HORZINEK, M.C., STUDDERT, M.J. (Ed.). Veterinary Virology, 3. ed. San Diego: Academic Press, 1999. 629 p. ROMERO, C.H., ROWE, C.A. Enzootic bovine leukosis vírus in Brazil. Trop. Anim. Health. Prod., v. 13, p. 107-111, 1981.

SANTOS, J.L., FARIA, J.E., RIBEIRO, M.F.B. Epidemiologia da leucose enzoótica bovina no Estado de Minas Gerais. I- Prevalência de anticorpos na zona da mata. Arq. Bras. Med. Vet. Zoot. v. 37, n. 4, p. 359-368, 1985.

SARGEANT, J.M., KELTON, D.F., MARTIN, S.W., MANN, E.D. Associations between farm management practices, productivity, and bovine leukemia virus infection in Ontario dairy herds. Prev. Vet. Med., v. 31, n. 3-4, p. 211-221, 1997.

SHIRLEY, J.E., SMITH, J.F., STOKKA, G.E., SCOBY, R.B.S. Dairy production management update: Bovine Leukosis. The Compendium Food Animal, n. 5, p. 651-654, 1997. 